\title{
Drying characteristics of Bael pulp using different drying methods and different varieties
}

Vipul Chaudhary, Vivak Kumar, B.R. Singh, Jaivir Singh, Neelash Chauhan and Pushpendra Kumar

Received : 07.01.2020; Revised : 24.01.2020; Accepted : 10.02 .2020

See end of the Paper for authors' affiliation

Correspondence to :

Vipul Chaudhary Department of Agricultural Engineering, Sardar Vallabhbhai Patel University of Agriculture and

Technology, Meerut (U.P.) India

Email: vipulchaudhary.in@ gmail.com
- ABSTRACT : Drying is an essential process in the preservation of agricultural products. Various drying methods are employed to dry different agricultural products. Each method has its own advantages and limitations. Choosing the right drying system is thus important in the process of drying agricultural products. An experimental study was performed to determine the drying characteristics of bael pulp subjected to drying in open sun, hot air oven at $60^{\circ} \mathrm{C}$ and $70^{\circ} \mathrm{C}$ and cabinet tray dryer at $60^{\circ} \mathrm{C}$ and $70^{\circ} \mathrm{C}$ with different varieties Pant Aparna $\left(\mathrm{V}_{1}\right)$, Pant Shivani $\left(\mathrm{V}_{2}\right)$ and Pant Urvashi $\left(\mathrm{V}_{3}\right)$. The entire drying process took place in the falling rate period. Drying curves were constructed using non-dimensional moisture ratio (MR) and time. Drying is the most widely used and a primary method for preservation. According to the experimental result this study revealed that the $\mathrm{V}_{1}$ (Variety Pant Aparna) sample required lower drying time than the other Varieties sample. The drying time decrease with increase of drying air temperature. It was observed that drying process took place in falling rate period. The result indicated that the cabinet tray dryer at $70^{\circ} \mathrm{C}$ was found better drying characteristics compare to other drying temperatures and methods.

- KEY WORDS : Bael pulp, Sun drying, Tray drying, Hot air oven drying, Moisture content, Moisture ratio, Drying rate

HOW TO CITE THIS PAPER : Chaudhary, Vipul, Kumar, Vivak, Singh, B.R., Singh, Jaivir, Chauhan, Neelash and Kumar, Pushpendra (2020). Drying characteristics of Bael pulp using different drying methods and different varieties. Internat. J. Agric. Engg., 13(1) : 19-30, DOI: 10.15740/ HAS/IJAE/13.1/19-30. Copyright@2020: Hind Agri-Horticultural Society. 